日本建築学会技術報告集 第24号，495，2006年12月 AlJ J. Technol. Des. No. 24, 495, Dec., 2006

\title{
既存建物のコンバージョンにおける避難安全性能の変化とその制御 一事務所から就寝施設への用途変更事例検証一
}

森山修治，長谷見雄二，藤村卓矢，木船麻里恵

青木義次 [東京工業大学大学院理工学研究科建築学専攻＼cjkstart教授・工博]

本研究は用途変更に伴い避難安全性能がいかに変化するかを検証 したものである。前報に引き続き，本報告では，事務所から共同住 宅・福祉施設などの就寝施設への用途変更の場合を議論している。 共同住宅では用途変更後に避難余裕時間が改善されていること, また，その理由が EV ホールと一体化された前室が階段に対する安 全区画として機能していることを指摘している。また，用途変更後 の共同住宅ではバルコニ一設置が不十分であり廊下が煙活染された 場合の安全性を考えるとき，この点を配慮すべき点として指摘して いる。さらに, 共同住宅での排煙設置, 福祉施設での居室排煙開口 の拡大と安全区画の設置を提案し, 避難安全性能の向上に効果的で あることを示している。

丹念に実例を分析すると同時に，用途変更種別ごとに安全性能向 上の具体的方法を提示している本研究を高く評価したい。
吉田克之 [(株)竹中工務店設計本部 工博] 避難安全検証法の妥当性については議論があるところだが、これ を適用してコンバージョン前後の避難性能の変化を比較することに は意義があると思う。しかし改善しても NG (余裕時間がマイナス) に留まった事例が 12 例中 9 例もあるのは, 相対比較としては評価で きても実務者としては不満である。どんな設計なら OKになるのか まで追求してほしいし，それでもだめならそれが建築主すなわち社 会の問題なのか検証法の問題なのか, この見解を示すまで論じてほ しい。NGの原因はいずれも小居室からの避難であり, 私はこれこそ が検証法の問題だと思っている。また余裕時間の平均值の上昇を もって全体的に改善されたというが, 個々の事例は個別に評価され るものなのだからこの考察は無理だと思う。ともあれ検証法はその 施行からはや 6 年, 大量の適用事例が出現したが, そろそろ見直しが 必要である。この一連の研究はその際の強力な資料になることを目 指してほしい。

\section{共振を考慮した人間の動作による床振動の測定，評価ならびに対策に関する一考察}

横山 裕, 井上竜太, 西谷伸介, 松下仁士, 柴田昭彦, 塚田幸一, 小林裕明 197

井上勝夫 [日本大学理工学部建築学科 教授. 工博] 一般に, 大スパン床構造の場合, 固有振動数の低下と共に減衰が 小さくなり, 歩行等に伴う体感振動上の問題が発生しやすくなる。 本報告は, この問題に対して加振源特性・スラブの振動特性・振動 伝搬特性について, それらの相互関係を含め実例により詳細に調査 したもので，発生原因の特定は実情の床構造評価等に関して有用な 計測事例と評価される。特に人の跳躍や歩行等の周波数特性とスラ ブの固有振動数, モードとの関係を論じた部分は, 同様な床構造の 設計・対策には，有用な知見を与えるものである。

ただし, 報告中で示している対策方法として，「分割跳躍による方 法」は, 床構造に同時入力される加振力自体が半分になっているこ との効果と本対策方法との比較, スラブの低次の共振周波数以外で は逆に増幅する結果が確認できることへの対処, 加振入力の時間差 を時系列応答波形上でみた場合の評価などの面で, 十分な検証が行 われているとは言い難い。今後，对策方法に対する検証事例を示す ことが期待される。
櫛田 裕 [神戸芸術工科大学デザイン学部環境・建築デザイン学科 教授・工博]

建物を取り巻く日常的な振動源に対する空間の供用性能を定量的 に評価し健全な居住・執務環境の創出を目的に建築学会で「建築物 の振動に関する居住性能評価指針・同解説」が刊行されてから 15 年 が経過した。今日まで，指針を拠り所に研究者・実務者は「設計と 評価」の一元化を計るべく実測デー夕を介して多くの研究に取組ん でいる。本報告はこの背詈を踏まえての一考察であるが設計, 研究 の両面から幾つかの示唆に富んだ課題が解読されるのでこれについ て述べておく。前半報告では設計の視点から a）床の振動解析に於 ける境界条件と固有振動性状への影響及びこれに基づく加振応答評 価位置の選定, 床咸性への小梁関与の考察等が挙げられる。研究の 視点からは b) 振動知覚確率評価等級と苦情発生確率との相関研 究, 複雑な床振動波形からの減衰定数の評価法等が挙げられる。

後半の報告は加振倍調波と床の卓越振動数との関連における床の 振動応答が詳細に考察されており振動応答制御に際して貴重な参考 資料を提供している。
塩田正純 [工学院大学工学部建築学科 工博]

本論文は，鉄道走行時に発生する地盤振動が，木造家屋内での振 動要因及び居住性能評価指針における評価曲線との適合について考 察，検討したものである。木造家屋各部位における振動性状につい て，1/3オクターブバンド分析による加速度值の最大值を基本とし て展開している。その測定量に影響を及ぼす変動要因として, 計測 器の時定数, 測定点までの距離, 列車の走行速度, 更には, 測定点 の違いについて考察している。また, 一定以上の列車速度の一般車 輌を対象として，その湘定值の平均值を性能評価曲線と照合してみ ると，上下線によって異なるが，対象振動数以上では，振動そのも のを体感している可能性を示唆している。したがって，鉄道走行時 に発生する地盤振動が，木造家屋に振動影響を与えているらしいこ とはうかがい知る事ができる。木造家屋に対する振動評価について の所見は，数少なく，今回の報告は，貴重な基礎デー夕になるもの と期待できる。更に，振動評価は，人間の全身振動をターゲットに するのか, 建築物の振動や摇れをターゲットにするのかの議論が必 要である。
石川毒重 [日本女子大学住居学科 教授・工博] 2004 年に大幅に改定された「建築物の振動に関する居住性能評価 指針」では, 評価に用いる物理量として 1/3オクターブバンド分析に よる加速度の最大值 $(\mathrm{O}-\mathrm{p})$ を基本とすることで，質の異なるデータ による評価の混乱を避けるように配慮した。そのため, 1/3オクタ一 ブバンド分析による測定データを蓄積し, 今後, 評価曲線の妥当性 を検証していくことが課題になっている。本稿は, 改訂版指針で提 示されたこのような条件を踏ま之, 環境振動湘定技術 WG（当時） が実施した振動測定の結果を, データとともに示している。木造家 屋に扔ける鉄道振動の測定事例は少なく，今回の測定は case 数もあ る程度多いことから, 測定点や速度などの条件との関連性を考察で きる貴重な資料となっている。本稿に提示された平均值による評価 だけでなく,より統計的なデー夕整理が望まれるが, 環境振動の居 住性能評価に関する有益なデータとして位置づけられる。 